\title{
Index 2000, Volume 1
}

\section{Editorials}

Personal Medical Services: accelerating the pace of change in primary health care

Yvonne Carter and Geoff Meads

Primary health care: does it defy definition? $R$ Bryar

Research and development: what is the difference?

$S$ Kendall

The social determinants of health: new life for primary health care

\section{John Macdonald}

\section{Networking articles}

Effective Health Care CHAIN (Contacts, Help, Advice and Information Network)

The European General Practice Research Workshop

The Federation of Primary Care Research Networks: a national initiative to enhance networking locally

\section{$H$ Smith}

Home blood pressure monitoring in type 2 diabetes: time to become as routine as fundoscopy?

$$
\text { Hugh Alberti }
$$

Practice-based research in the United States

$$
\text { John W Beasley }
$$

Research interest groups - the way to a collaborative approach?

$$
\text { M Lee }
$$

\section{Development articles}

A citizens' advice service in primary care: improving patient access to benefits Margaret Sherratt, Kevin Jones and Peter Middleton

Easing the burden on primary care in deprived urban areas: a service model

Stephen Abbott and Lis Davidson Is there an evidence base for intuition and empathy? The risks and benefits of inviting an older person to discuss unresolved loss

$$
\text { E Peile }
$$

The potential of information technology for nurses in primary care: a review of issues

133 and trends

$$
\text { L Alpay, G Needham and P Murray }
$$

\section{Research articles}

Adolescents' experiences of maltreatment within the family: challenges for family nursing

Eija Paavilainen, Päivi Åstedt-Kurki and

\section{Marita Paunonen}

Antenatal screening in the community: the views and experience of women in one general practice

JE Thistlewaite and J Jordan

197 Care of the frail elderly in the community: a critical incident study

199 Louise Robinson and Chris Drinkwater A comparison of two fixed-term research

3 and development projects that involved collaboration with practices

Bill Bytheway

Do we need asthma clinics in primary care?

198 Patients' views and perspectives

Alan Jones, Roisin Pill and

Stephanie Adams

Freight trains and supernovas: the use of a

135 sorting task to determine patterns within long-term frequent attendance to general

69 practitioners

RD Neal, PL Heywood and S Morley

Integrated nursing teams: in whose interests? Claire Goodman

The invisible work of the district nursing

139 team: methodological problems associated with exploring skills

\section{$J$ McIntosh}

Interviewing children for the purposes of

201 research in primary care

$M$ Morison, J Moir and T Kwansa

Joint commissioning for mental health

71 services between primary health care and social care in Wales

Jenny Secker, Pat Davies and

Valerie Howell

5 Patients' perceptions of changing 
professional boundaries and the future of 'nurse-led' services

A Chapple, A Rogers, W Macdonald and $M$ Sergison

Providing new insight into community nursing know-how through qualitative analysis of multiple sets of simulation data A Bryans

Public health nursing: a comparison of theoretical and actual practice

J Besner

Reactions of general practitioners, district nurses and specialist providers to the development of a community palliative care service

C Ingleton

Relationships between the key players in primary care groups and trusts: some lessons from total purchasing pilots

Brenda Leese and Ann Mahon Utilizing the Maslach Burnout Inventory to measure burnout in HIV/AIDS specialist community nurses: the implications for clinical supervision and support

Mark Hayter

Variations in administration of depot antipsychotic medication within primary care: a cross-sectional survey of practices in the North Thames Region

Ilyas $Q$ Mirza and Michael Phelan

\section{Book reviews}

Coulter, A. and Ham, C., editors The global challenge of health care rationing (reviewer: Rhiannon Tudor Edwards)

91 Handy, C. The new alchemists (reviewer: Andrew Price)

Malin, N., Manthorpe, J., Race, D. and

15 Wilmot, S. Community care for nurses and the caring professions (reviewer: Julia Johnson)

McIntosh, J., editor. Research issues in community nursing

153 (reviewer: Gill Hek)

Morgan, K. and Closs, S.J. Sleep

management in nursing practice (reviewer: Peter Campion)

243 Peters, T. The circle of innovation (reviewer: Andrew Price)

Tovey, $\mathrm{P}$, editor. Contemporary primary care - the challenges of change (reviewer: Geoff Meads)

147 Wilson, T., editor. The PCG development guide

(reviewer: Paul Hocking)
191

\title{
Author index
}

\author{
Abbott, S., 201 \\ Adams, S., 229 \\ Alberti, H., 198 \\ Alpay, L., 5 \\ Åstedt-Kurki, P., 235 \\ Beasley, J.W., 135 \\ Besner, J., 91 \\ Bryans, A., 79 \\ Bryar, R., 1 \\ Bytheway, B., 217 \\ Carter, Y., 133 \\ Chapple, A., 51 \\ Davidson, L., 201 \\ Davies, P., 179 \\ Drinkwater, C., 163
}

Goodman, C., 207

Hayter, M., 243

Heywood, P.L., 39

Howell, V., 179

Ingleton, C., 15

Jones, A., 229

Jones, K., 139

Jordan, J., 29

Kendall, S., 65

Kwansa, T., 113

Lee, M., 69

Leese, B., 153

Macdonald, J., 195

Macdonald, W., 51

Primary Health Care Research and Development 2001; 2: 266-270 
Mahon, A., 153

McIntosh, J., 103

Meads, G., 133

Middleton, P., 139

Mirza, I.Q., 147

Moir, J., 113

Morison, M., 113

Morley, S., 39

Murray, P., 5

Neal, R.D., 39

Needham, G., 5

Paavilainen, E., 235
Paunonen, M., 235

Peile, E., 71

Phelan, M., 147

Pill, R., 229

Robinson, L., 163

Rogers, A., 51

Secker, J., 179

Sergison, M., 51

Sherratt, M., 139

Smith, H., 3

Thistlewaite, J.E., 29

\section{Index 2001, Volume 2}

\section{Editorials}

Are primary care research networks up to the challenge?

Pali Hungin and Greg Rubin

Is primary care reform the political route to primary health care?

Ginette Lemire Rodger

Private troubles, public issues: the case of family care

Carmen de la Cuesta

WANTED: Articles on development of PHC services and practice

Rosamund Bryar and Sally Kendall

\section{Networking articles}

Next steps for primary care research networks?

Paul Thomas

A novel approach to research presentations

for networks: an evaluation of Visual

Presentation with Expert Review (ViPER)

Michael Moore, Helen Smith,

Joan Dunleavey, Jenny Field, Angela

Fenwick, Peter White, and Alison

Woodcock

Opening the black box: qualitative methods

training from the Wolds Primary Care

Research Network (WoReN)

Report from Amelia Island, Florida Mirilee Pearl

Research in cardiovascular disease: meeting

the challenges of the National Service

67 Framework

Pali Hungin

135

\section{Development articles}

Developing sustainable collaboration:

203 learning from theory and practice

Teri Knight, Judith Smith and

Stephen Cropper

1 Evaluating newly commissioned services in primary care: lessons from a force field analysis

Clare Grant and Chris Hine

137 Research articles

Clinical guidelines for the promotion of continence in primary care: community

205 nurses' knowledge, practice and perceptions of their role

Vivien Bignell and Kathryn Getliffe

Comparison of traditional GP oral anticoagulation management with a nurseled service involving near patient testing and computerized decision support

5 Paul Barber, Susan Backhouse,

Susan Timon, Clive Lawrence and

David Seamark

69 The effectiveness of home visiting as a delivery strategy for public health nursing

3 interventions to clients in the prenatal and

Primary Health Care Research and Development 2001; 2: 266-270 